\title{
SMALL DOSES OF PREDNISOLONE IN THE MANAGEMENT OF RHEUMATOID ARTHRITIS
}

\author{
J. R. DE ANDRADE*, J. N. MCCORMICK, AND A. G. S. HILL \\ From the Oxford Regional Rheumatism Research Centre, Stoke Mandeville Hospital, Aylesbury, Bucks.
}

Throughout its 15-year history the treatment of rheumatoid arthritis with corticosteroids has presented clinicians with a succession of differing aspects - first a brief flash of hope that most of the problems of the disease had been solved, then a sombre picture of impermanent benefit bought at too great a cost in terms of undesirable effects, and last a more balanced scene of limited objectives and greatly reduced dangers. The dose of cortisone empirically chosen for the earliest clinical trials (Hench, Kendall, Slocumb and Polley, 1949) was commonly $100 \mathrm{mg}$./ day, equivalent to about $20 \mathrm{mg}$. prednisolone. Prolongation of treatment at this level of administration soon revealed the adverse effects which induced many clinicians to abandon the use of corticosteroids entirely and others to accept the less complete control of the disease but greater safety offered by smaller doses, and 6 years later Polley, Slocumb, Ward, and Hench (1955) recommended maintenance doses of 25 to $30 \mathrm{mg}$./day cortisone for women after the menopause, 35 to $40 \mathrm{mg}$. before the menopause, and 40 to $50 \mathrm{mg}$./day for men. In terms of prednisolone these doses fall within the range of 5 to $10 \mathrm{mg}$./day. In a trial comparing aspirin with prednisolone in the treatment of rheumatoid arthritis organized in Great Britain by a joint committee of the Medical Research Council and Nuffield Foundation (1960), the starting dose of prednisolone was $20 \mathrm{mg}$./day, but by the end of the third year the mean dose had fallen to $10.5 \mathrm{mg}$.

In this report we present the results of observations made in patients with rheumatoid arthritis in whom the total daily dose of prednisolone was 5 or $7.5 \mathrm{mg}$. and in whom higher doses had never been used. Our use of prednisolone in these low doses arose from observations made in the course of studying the phenomenon of morning stiffness, so characteristic a feature of rheumatoid arthritis. Earlier work at

\footnotetext{
* Present address: State University of New York at Buffalo, School
} of Medicine, 100 High Street. Buffalo 3, N.Y. this centre by Wright (1959) had shown that adrenal stimulation with a long-acting preparation of corticotrophin could abolish diurnal changes in strength of grip. It was postulated that morning stiffness is related to the diurnal rhythm of the plasma cortisol level, which is lowest at night (Ward, Wu, Hench, Mason, Slocumb, Polley and Mayne, 1958), and that this physiological rhythm is abolished by continuous adrenal stimulation with a long-acting preparation of corticotrophin. A dose of prednisolone timed so as to raise the nocturnal level of circulating corticosteroid might be expected to have a similar effect. To test this theory measurements of grip were made throughout the early morning hours in patients to whom $5 \mathrm{mg}$. prednisolone had been given at 10 p.m. Objective lessening of morning stiffness was apparent in a few of these measurements, but subjective relief was more striking and led, tentatively at first, to the use of the same small evening dose as a deliberate therapeutic measure. As experienced lengthened and the safety of this small dose became more apparent, it was used in a larger number of cases - eventually including many with rheumatoid arthritis of short duration, in which corticosteroid therapy would not have been contemplated at a time when it was customary to use higher doses. Relieved of morning stiffness, often their major disability, many patients found it possible to complete the day's activities without further treatment. Stiffness tended to increase in the evening in a few patients and in these an additional dose of 2.5 mg. was given at mid-day.

Since the scheme of treatment had evolved largely from the uncontrolled observation of a subjective improvement in morning stiffness, the efficacy of this therapeutic manœuvre was evaluated in a controlled trial. The object was to compare, in a double-blind experiment, the subjective effects of 5 mg. prednisolone given at night with those of the same dose given in the morning. To complement 
this appraisal of the therapeutic effect of treatment, a survey was also conducted of its undesirable effects and these observations were compared with the effects experienced by patients treated with larger doses. In addition, tests for pituitary-adrenocortical reserve were made in a number of patients who had been treated with $5 \mathrm{mg}$. prednisolone daily for 100 to 180 weeks.

\section{Methods}

All patients satisfied the criteria of the American Rheumatism Association (1959) for the diagnoses "probable", "definite", or "classical" rheumatoid arthritis and all complained of morning stiffness as a prominent symptom.

Clinical Trial: 56 patients were inciuded in the doubleblind trial. None of them had at any time taken a dose of corticosteroid larger than $5 \mathrm{mg}$. prednisolone. $42 \mathrm{had}$ already been taking $5 \mathrm{mg}$. prednisolone at night (mean duration 64 weeks).

In this trial patients took one tablet at 10 p.m. and a second, identical in appearance, in the morning; one tablet contained $5 \mathrm{mg}$. prednisolone and the other an inert placebo. For each patient the 4-week trial was divided into 2-week periods. In each period the evening tablet contained prednisolone during one week, and the morning tablet during the other week. The sequence of evening and morning prednisolone weeks was prearranged according to a randomized schedule and was not revealed to the patient or the observer until the whole trial was completed. For each week the patient was given two packets, marked with the number of the week (1-4) and the time of day at which one of the tablets was to be taken. In effect each patient was the subject of two identicai trials and the result was accepted as significant only if it consistently favoured morning or evening administration of prednisolone in both. Each patient was provided with a form on which he was asked to compare the degree of morning stiffness experienced during each week. To avoid observer bias the patient was not interviewed between the beginning of the trial and the return of his form by post.

Adverse Effects: These were regarded as "severe" if they enforced interruption of treatment and "mild" if they did not. Data are also presented for all deaths occurring during treatment with high and low doses; since it is not always possible to decide whether corticosteroid therapy has contributed to a fatal issue we believe it desirable in a report such as this to place this information on record.

Pituitary-adrenocortical Reserve: Tests for pituitaryadrenocortical reserve were carried out in ten patients who had had $5 \mathrm{mg}$. prednisolone daily at $10 \mathrm{p} . \mathrm{m}$. for from 100 to 180 weeks. These tests were based on the method described by Liddle, Estep, Kendall, Williams, and Townes (1959) using methopyrapone* (S.U. 4885;

\footnotetext{
* Metopirone-Ciba.
}

2-methyl -1, 2 bis (3 pyridyl) -1-propanone). Urinary ketogenic steroids were measured by the method described by Norymberski, Stubbs, and West (1953). The results of these tests have been reported elsewhere (de Andrade, in press).

\section{Results}

Clinical Trial.-Of the 56 patients in whom the response to $5 \mathrm{mg}$. prednisolone given at night was compared with the effect of the same dose given in the morning, 49 provided data suitable for analysis. Of the remaining seven, four did not understand what was required, two provided insufficient data, and the last was admitted to hospital during the trial.

The results are summarized in Table I, which shows that the result was inconsistent in nineteen cases in that either one time of administration was preferred in the first 2-week period and the other in the second (eighteen cases) or no choice could be made (one case). Of the thirty who expressed a consistent preference, 28 had less morning stiffness when prednisolone was given in the evening and only two when it was given in the morning.

TABLE I

RESULTS OF CLINICAL TRIAL

\begin{tabular}{|c|c|c|c|c|}
\hline \multicolumn{4}{|c|}{ Choice of Treatment } & No. of Patients \\
\hline $\begin{array}{l}\text { Evening Dose.. } \\
\text { Morning Dose } \\
\text { Inconsistent } \\
\text { None } \\
\text { Disqualified } \quad . \\
\end{array}$ & $\begin{array}{l}\cdots \\
\cdots \\
\cdots \\
\cdots \\
\cdots\end{array}$ & $\begin{array}{l}\ldots \\
\cdots \\
\cdots \\
\cdots\end{array}$ & $\begin{array}{l}\cdots \\
\cdots \\
\cdots \\
\cdots \\
\end{array}$ & $\begin{array}{r}28 \\
2 \\
18 \\
1 \\
7 \\
\end{array}$ \\
\hline & otal & . & . & 56 \\
\hline
\end{tabular}

The results of this short trial suggested that, in the majority of patients, a small evening dose of prednisolone was more effective than the same dose given in the morning. Some patients who had been taking prednisolone for long periods had an increase in morning stiffness when the time of administration was changed without their knowledge from evening to morning.

One advantage of using small doses of prednisolone proved to be the ease with which treatment could be abandoned. Among ninety patients who started taking prednisolone in daily doses of 5 to $7 \cdot 5 \mathrm{mg}$. during 1958 and 1959, treatment was discontinued within 2 years in seventeen-in fourteen because it was no longer required and in three because of major adverse effects. Though treatment was stopped abruptly, none of these patients suffered the "rebound" exacerbation of symptoms familiar in those from whom prednisolone is withdrawn after the prolonged use of higher doses. 
Adverse Effects.-Details of adverse effects of treatment with prednisolone in relation to duration and dosage are given in Table II, from which the following conclusions emerge:

(1) Some patients will have severe adverse effects from all therapeutic doses of prednisolone, however low. Such effects tend to occur early (within 25 weeks) and once these vulnerable patients have been discovered and their treatment stopped, the remainder will experience few severe adverse effects throughout treatment with prednisolone in daily doses of 5 to $7.5 \mathrm{mg}$. The mild adverse effects, notably bruising, seem to be related to the duration of treatment. Nocturnal frequency of micturition was commonly reported by patients taking $5 \mathrm{mg}$. prednisolone at bedtime.

(2) On a daily dosage of $10 \mathrm{mg}$. prednisolone or more, adverse effects increase pari passu with dosage and duration of treatment.

(3) The incidence and dose-relationship of adverse effects make the use of larger doses unjustifiable in the majority of patients, but warrant the use of small doses, even in fairly mild cases. The area of unacceptable risk is entered at a dose level in the region of $10 \mathrm{mg}$. $/ 24 \mathrm{hrs}$.

Corticosteroid treatment may have been to some extent responsible for the seven fatalities included in
Table II. It was possibly a significant factor in the death from infection of three patients and of one who had arteritis and neuropathy, and it was probably responsible in three cases for death ascribed to adrenal failure (no biochemical data available).

Five patients were treated with betamethasone and five with triamcinolone. These patients, together with four treated with corticotrophin, have not been considered in the study of side-effects.

The incidence of adverse effects may have been influenced to some extent by the severity of the disease and in general high doses were used at an earlier stage in our experience of corticosteroid therapy when only severe cases were accepted for such treatment. We do not believe, however, that this reservation materially affects our conclusions.

The change in policy from treating a minority of patients with high doses to accepting larger numbers, including early and mild cases for treatment with small doses is indicated in Table III (opposite). These figures reflect a growing awareness of the unacceptable risks of high dosage and the relative safety of low doses.

Pituitary-adrenocortical Reserve.-The results of tests for pituitary-adrenocortical reserve suggested that some function was present in all ten patients studied (de Andrade, 1964).

TABLE II

ADVERSE EFFECTS OF TREATMENT WITH PREDNISOLONE WITH RELATION TO DURATION OF TREATMENT AND DOSAGE

\begin{tabular}{|c|c|c|c|c|c|c|c|c|c|c|}
\hline \multicolumn{5}{|c|}{$\begin{array}{c}\text { Duration of Treatment } \\
\text { (weeks) }\end{array}$} & \multicolumn{2}{|c|}{ Less than 25} & \multicolumn{2}{|c|}{$25-50$} & \multicolumn{2}{|c|}{ Over 50} \\
\hline \multicolumn{3}{|c|}{ Prednisolone (mg./24 hrs.) } & $\cdots$ & $\cdots$ & $\begin{array}{l}\text { Less than } \\
10\end{array}$ & $\begin{array}{l}10 \text { or } \\
\text { More }\end{array}$ & $\begin{array}{c}\text { Less than } \\
10\end{array}$ & $\begin{array}{l}10 \text { or } \\
\text { More }\end{array}$ & $\begin{array}{l}\text { Less than } \\
10\end{array}$ & $\begin{array}{l}10 \text { or } \\
\text { More }\end{array}$ \\
\hline \multicolumn{3}{|c|}{ No. Patients Treated .. } & $\cdots$ & $\cdots$ & 39 & 13 & 50 & 32 & 137 & 42 \\
\hline \multirow{6}{*}{$\begin{array}{l}\text { Adverse } \\
\text { Effects }\end{array}$} & \multirow{3}{*}{ Minor } & \multirow{2}{*}{ Total } & No. & & 2 & 1 & 1 & 1 & 13 & 4 \\
\hline & & & $\%$ & & 5 & 8 & 2 & 3 & 9 & 10 \\
\hline & & \multicolumn{2}{|c|}{$\begin{array}{l}\text { Gastro-intestinal } \\
\text { Purpura, bruising }\end{array}$} & $\cdots$ & $\begin{array}{l}1 \\
1\end{array}$ & 1 & 1 & 1 & $\begin{array}{l}5 \\
8\end{array}$ & $\begin{array}{l}1 \\
3\end{array}$ \\
\hline & \multirow[b]{3}{*}{ Major } & \multirow{2}{*}{ Total } & No. & & 7 & 3 & 1 & 12 & 4 & 20 \\
\hline & & & $\%$ & & 18 & 23 & 2 & $37 \cdot 5$ & $2 \cdot 9$ & $47 \cdot 5$ \\
\hline & & \multicolumn{2}{|c|}{$\begin{array}{l}\text { Gastro-intestinal } \\
\text { Hypercortisonism } \\
\text { Depression } \\
\text { Muscle abscess }\end{array}$} & $\begin{array}{l}\cdots \\
\cdots \\
\cdots \\
\cdots \\
\cdots \\
\cdots\end{array}$ & $\begin{array}{r}5 \\
1 \\
1 \\
- \\
- \\
-\end{array}$ & $\begin{array}{l}1 \\
= \\
= \\
= \\
-\end{array}$ & $\begin{array}{l}1 \\
- \\
- \\
- \\
-\end{array}$ & $\begin{array}{r}6 \\
4 \\
+2 \\
- \\
- \\
-\end{array}$ & $\begin{array}{l}2 \\
= \\
\bar{Z} \\
* 1(\mathrm{~d}) \\
-\end{array}$ & $\begin{array}{l}8 \\
6 \\
- \\
2(d) \\
1(d) \\
3(1 d)\end{array}$ \\
\hline
\end{tabular}

(d) Died

$\ddagger$ Intramuscular prednisolone 
TABLE III

CHANGES IN PROPORTION OF PATIENTS WITH RHEUMATOID ARTHRITIS TREATED WITH PREDNISOLONE AND IN DOSAGE EMPLOYED DURING THE YEARS 1954-1961

\begin{tabular}{|c|c|c|c|c|c|c|c|c|c|c|c|}
\hline Year & $\cdots$ & $\cdots$ & $\cdots$ & 1954 & 1955 & 1956 & 1957 & 1958 & 1959 & 1960 & 1961 \\
\hline No. of New Cases & $\cdots$ & $\cdots$ & $\cdots$ & 62 & 82 & 116 & 104 & 118 & 119 & 153 & 101 \\
\hline \multicolumn{2}{|c|}{ No. Treated with Prednisolone } & $\ldots$ & $\ldots$ & 2 & 5 & 11 & 13 & 49 & 49 & 65 & 54 \\
\hline Daily Dose (mg.) & $\begin{array}{l}\text { Below } 10 \\
10-19 \\
20 \text { or More }\end{array}$ & & & $\begin{array}{l}0 \\
1 \\
1\end{array}$ & $\begin{array}{l}0 \\
3 \\
2\end{array}$ & $\begin{array}{l}0 \\
3 \\
8\end{array}$ & $\begin{array}{r}1 \\
11 \\
1\end{array}$ & $\begin{array}{r}43 \\
6 \\
0\end{array}$ & $\begin{array}{r}46 \\
3 \\
0\end{array}$ & $\begin{array}{r}57 \\
8 \\
0\end{array}$ & $\begin{array}{r}51 \\
3 \\
0\end{array}$ \\
\hline
\end{tabular}

\section{Discussion}

The results of this investigation permit only limited conclusions about the value of small doses of corticosteroid in the management of rheumatoid arthritis. That $5 \mathrm{mg}$. prednisolone given at night can reduce or eliminate morning stiffness in the majority of patients was quickly apparent and was confirmed by altering the time of administration from night to morning and vice versa in random fashion and under double-blind conditions. As experience of this effect in early and mild cases accumulated, it became increasingly apparent that many patients were content to have only this feature of their disease controlled. We have no data relating to the effect on the progress of the disease, but it would be surprising if so low a dose could retard deterioration in the joints, assessed radiographically.

A few patients treated with a single dose at night complain of a return of stiffness towards evening; this can be reduced by adding a supplementary dose of $2.5 \mathrm{mg}$. at noon or at a time found by experiment to produce the best result. Our present policy is not to exceed a daily total of $7.5 \mathrm{mg}$. in any but exceptional circumstances. The clinical response is better when low doses are used ab initio than when they are reached during an enforced retreat from higher levels. When regarded as an ancillary to a basic regime of rest, splinting, and graded exercises, prednisolone in these doses can produce useful symptomatic relief, especially in mild cases.

As might be expected, signs of overdosage are rarely produced by such small amounts of corticosteroid and apart from bruising the only common undesirable effect is dyspepsia. This can often be relieved by avoiding aspirin, by giving antacids, or by recommending that the tablets be taken crushed with milk. More severe or intractable dyspepsia is the commonest contra-indication to continuing treatment. As the safety of low doses became apparent, treatment was started with less hesitation in early and mild cases of rheumatoid arthritis. Since suppression of the pituitary-adrenocortical axis is one of the most serious effects of treatment with corticosteroids, it was reassuring to find that some pituitary-adrenocortical reserve was preserved after prolonged treatment with $5 \mathrm{mg}$. prednisolone. We have not, however, considered it politic to relax the usual precautions in patients undergoing surgical operations during or after treatment with prednisolone, and in all cases supplementary doses of cortisone are given before operation.

\section{Summary}

In many patients with rheumatoid arthritis a single dose of $5 \mathrm{mg}$. prednisolone taken at bedtime markedly reduced morning stiffness. Among the patients able to detect a difference in the effect of 5 mg. prednisolone taken in the morning as compared with the same dose taken at night, the majority favoured the evening dose.

Adverse effects of treatment with prednisolone were compared in patients treated with a total daily dose of 5 to $7.5 \mathrm{mg}$. and in those receiving higher doses. Severe adverse effects from low doses were mainly gastro-intestinal and occurred in the early stages of treatment. After patients suffering such effects had been discovered and their treatment stopped, prolongation of therapy in the remainder rarely produced fresh major adverse effects, though the incidence of purpura and bruising continued to increase. By contrast, the major adverse effects of higher doses of corticosteroid occurred at any time but more often when treatment was prolonged.

Pituitary-adrenocortical reserve was found to be present in all of ten patients who had taken $5 \mathrm{mg}$. prednisolone daily for up to $3 \frac{1}{2}$ years.

If doses of prednisolone in the range 5 to $7.5 \mathrm{mg}$. are not exceeded, treatment with corticosteroids is justifiable in relatively early and mild cases of rheumatoid arthritis. The clinical response is better if such doses have not been preceded by a period of higher dosage. No claim is made that low doses produce other than symptomatic benefit. 


\section{REFERENCES}

Andrade, J. R. de (1964). J. clin. Endocr. (In press).

Hench, P. S., Kendall, E. C., Slocumb, L. H., and Polley, H. F. (1949). Proc. Mayo Clin., 24, 181.

Liddle, G. W., Estep, H. L., Kendall, J. W., Jr., Williams, W. C., and Townes, A. W. (1959). J. clin. Endocr., 19,875 .

Medical Research Council and Nuffield Foundation Joint Committee on Clinical Trials of Cortisone, ACTH, and Other Therapeutic Measures in Chronic Rheumatic Diseases (1960). Ann. rheum. Dis., 19, 331 .

Norymberski, J. K., Stubbs, R. D., and West, H. F. (1953). Lancet, 1, 1276.

Ropes, M. W., Bennett, G. A., Cobb, S., Jacox, R., and Jessar, R. A. (1959). Ann. rheum. Dis., 18, 49.

Polley, H. F., Slocumb, L. H., Ward, L. E., and Hench, P. S. (1955). Ibid., 14, 416.

Ward, L. E., Wu, Chung, Hench, P. S., Mason, H. L., Slocumb, L. H., Polley, H. F., and Mayne, J. G. (1958). Proc. Mayo Clin., 33, 611.

Wright, V. (1959). Clin. Sci., 18, 17.

\section{Faibles doses de prednisolone dans le maniement} de l'arthrite rhumatismale

\section{RÉSUMÉ}

Chez beaucoup de malades atteints d'arthrite rhumatismale une seule dose de $5 \mathrm{mg}$. de prednisolone, prise à l'heure du coucher, réduit appréciablement l'enraidissement matinal. La plupart des malades, capables de distinguer entre l'effet de $5 \mathrm{mg}$. de prednisolone, pris le matin, et celui de la même dose, prise le soir, préfèrent la dose du soir.

On a comparé les effets secondaires de la prednisolone à une dose de 5 à $7,5 \mathrm{mg}$. par jour à ceux survenant avec des doses plus fortes. Les effets secondaires sévères, produits par des doses faibles, étaient surtout gastrointestinaux et survenaient à la période initiale du traitement. Dès qu'on notait ces effets, on arrêtait le traitement. On le continuait chez les autres malades chez qui, dans la suite, de majeurs effets défavorables ne survenaient que rarement, mais la fréquence du purpura et des ecchymoses tendait à augmenter. Par contre, des effets défavorables majeurs des doses plus fortes du corticostéroïde survenaient n'importe quand, mais plus souvent après un traitement prolongé.

On a trouvé que la réserve adrénocortico-pituitaire était présente chez tous les 10 malades traités par $5 \mathrm{mg}$. de prednisolone par jour pendant des périodes allant jusqu'à $3 \frac{1}{2}$ ans.

Si l'on ne dépasse pas la dose de 5 à $7 \mathrm{mg}$., le traitement corticostéroïde est justifiable dans des cas d'arthrite rhumatismale relativement précoce et benigne. La réponse clinique est meilleure chez des malades qui n'ont pas subi antérieurement un traitement par des doses plus fortes. On ne prétend pas que de faibles doses produisent un effet autre que symptomatique.

\section{Pequeñas dosis de prednisolona en el tratamiento de la artritis reumatoide}

\section{Sumario}

En muchos enfermos con artritis reumatoide una sola dosis de $5 \mathrm{mg}$. de prednisolona, tomada antes de acostarse, reduce apreciadamente la rigidez matinal. La mayoría de los enfermos que pueden diferenciar entre el efecto de $5 \mathrm{mg}$. de prednisolona tomada por la mañana y el efecto de la misma dosis tomada por la noche, prefieren la última dosis.

Se compararon los efectos secundarios de la prednisolona en dosis de 5 a $7,5 \mathrm{mg}$. diarios a los que ocurren con dosis más fuertes. Los efectos secundarios graves, producidos por las dosis pequeñas, fueron principalmente gastro-intestinales y sobrevinieron durante el período inicial del tratamiento. A notar estos efectos, se interrumpía el tratamiento, continuándole en los demás enfermos en los cuales una terapia prolongada producía raramente mayores efectos secundarios, aunque la frecuencia de purpura y de equimosis siguiese aumentando. En cambio, efectos secundarios mayores debidos a dosis más fuertes de corticosteroides ocurrían en cualquier tiempo, lo más a menudo al prolongarse el tratamiento.

La presencia de la reserva adrenocortico-pituitaria fué confirmada en los 10 enfermos tratados con $5 \mathrm{mg}$. de prednisolona diaria durante períodos de hasta $3 \frac{1}{2}$ años.

A no rebasar una dosis de 5 a $7 \mathrm{mg}$., el tratamiento corticosteroide se ve justificado en casos de artritis reumatoide relativamente precoz y benigna. La respuesta clínica es mejor en enfermos que no habían sido tratados anteriormente con dosis más fuertes. No se pretende aquí el tratamiento con dosis pequeñas ofrezca un beneficio más que sintomático. 